\title{
Cancer incidence and specific occupational exposures in the Swedish leather tanning industry: a cohort based case-control study
}

\author{
Zoli Mikoczy, Andrejs Schütz, Ulf Strömberg, Lars Hagmar
}

\begin{abstract}
Objective-To study the effect on the incidence of cancer of exposure to chemicals handled in the leather tanning industry. Materials and methods-A case-control study was performed within a cohort of 2487 workers employed for at least six months during the period 1900-89 in three Swedish leather tanneries. 68 cancer cases (lung, stomach, bladder, kidney, nasal, and pancreatic cancers and soft tissue sarcomas) and 178 matched controls were studied. Effects of chemical exposures on cancer incidence, adjusted for age at risk, sex, and plant were estimated with a conditional logistic regression model.
\end{abstract}

Results-A significant association was found between exposure to leather dust and pancreatic cancer (odds ratio (OR) $7 \cdot 19,95 \%$ confidence interval $(95 \% \mathrm{CI})$ 1.44 to $35 \cdot 89$ ). An association was indicated between leather dust from vegetable tanning and lung cancer. After adjustment for smoking habits a tentative association between organic solvents and lung cancer lost its significance. No association was found between exposure to chlorophenols and soft tissue sarcomas.

Conclusions-The significant association between leather tanning and soft tissue sarcomas that was found in our previous cohort analysis could not be explained by exposure to chlorophenols. On the other hand a significant association was found between exposure to leather dust and pancreatic cancer, and exposure to leather dust from vegetable tanning was often present in cases with lung cancer. Due to the small numbers of cases, the results can, however, only lead to tentative conclusions.

(Occup Environ Med 1996;53:463-467)

Department of Occupational and Environmental Medicine, University Hospital, S-221 85 Lund, Sweden Z Mikoczy A Schütz

U Strömberg

L Hagmar

Correspondence to: Dr Z Mikoczy, Department of Occupational and Environmental Medicine, University Hospital, S-22 85 Lund, Sweden.

Accepted 26 February 1996 vents, formaldehyde, and chlorophenols. Furthermore, methyl mercury, which has been shown to cause genetic damage, has been handled in the tanneries.
An association between leather tanning and lung cancer has been shown in some, ${ }^{2-4}$ but not all, ${ }^{5-7}$ previous studies. In earlier Swedish studies increased risks of pancreatic cancer ${ }^{6}$ and kidney cancer ${ }^{8}$ have been found among leather tanners. In some cohort studies, an excess of soft tissue sarcomas was indicated. ${ }^{59}$ Slightly increased risks of bladder cancer have been found among workers in tanning and leather processing plants, ${ }^{1011}$ but not in all studies. ${ }^{712} 13$ Exposure to leather dust in the shoe and boot industry has caused an increased risk of sinonasal cancer. ${ }^{14}$ Such an increased risk has also been indicated for workers in the tanning and leather processing industry. ${ }^{515} \mathrm{~A}$ numerical but non-significant excess of stomach cancer has been reported for male shoe workers. ${ }^{2}$

In a cohort study of leather workers from three Swedish tanneries we found a significantly increased incidence of soft tissue sarcomas, and also excesses of multiple myelomas and sinonasal cancer. ${ }^{16}$ To assess the associations between specific occupational exposures in the leather tanning industry and cancer incidence, a nested case-control study has now been performed within this cohort.

\section{Subjects and methods}

STUDY BASE

The study base comprised 2487 employees who had been employed for at least six months during the period 1900-89 in three Swedish leather tanneries. Vital status was found as of December 1989 , and 1924 subjects $(77 \cdot 4 \%)$ were at that time living in Sweden, 525 $(21 \cdot 1 \%)$ were dead, $32(1.3 \%)$ had emigrated, and six subjects $(0 \cdot 2 \%)$ were lost to follow up. Information on tumours (coded according to the international classification of diseases, 7 th revision (ICD-7)) diagnosed from 1958-89, was obtained from the National Swedish Tumour Registry.

SELECTION OF CASES AND CONTROLS

Altogether 70 subjects from the study had tumours diagnosed earlier as associated with leather tanning; 24 with lung cancer, nine with stomach cancer, 16 with bladder cancer, six with kidney cancer, one with nasal cancer, four with soft tissue sarcomas, and 10 with pancreatic cancer, were selected as cases. For each case three controls (whenever possible) were selected from the study base. Incidence density sampling ${ }^{17}$ was used; controls were randomly selected from those being followed up at the age of onset of each case. Cases and 
controls were also matched by plant and sex. In the analysis an induction latency period of at least 10 years was used, by excluding the subjects from analysis during their first 10 years since the start of employment. Because of this restriction two cases and four controls were excluded. Moreover, work histories could not be retrieved for 16 controls, and five controls were no longer eligible as their matched case had been excluded. The analyses were thus restricted to 68 cases and 178 controls. Table 1 shows the distribution of cases and controls by sex, plant, and matched sets.

\section{PRODUCTION}

Plant A was run between 1906 and 1988, with chrome tanning as the dominating process. Hexavalent chromium salts were reduced to trivalent chromium from 1906 up to the mid1960s, after which only trivalent chromium was handled in the plant. A minor department at the plant produced leather tanned by vegetable dyes until the late 1960s. Plant B was run between 1897 and 1989. For tanning, vegetable tannins, formaldehyde, aluminium, and chromium compounds were used. Vegetable tanning of leather was carried out until 1935. From 1930 to 1955 the plant reduced hexavalent chromium to trivalent chromium, and, from 1955 until the close down in 1989 trivalent chromium salts were used. Plant $C$ was run between 1860 and 1991 . Vegetable tanning was entirely dominant until 1960. During the 1960 s, the production was changed almost completely to chromium tanned leather. Only trivalent chromium was handled at this plant. Raw hides imported to plant $B$ and $C$ up to 1940 most probably contained arsenic compounds as preservatives. In all three plants arsenic sulphides were used for soaking and unhairing until about 1950. Mercury compounds may also have been used for the same purpose. At all three plants, organic mercury preservatives seem to have been used during the 1940s and 1950s. During the 1950s, the mercury compounds were replaced by chlorophenols, which were used until the beginning of the $1980 \mathrm{~s}$, and at plant $\mathrm{B}$ also during the second half of the 1980s. Both aniline and azo dyes have been used extensively for leather dyeing. The use of paints based on organic solvents have varied considerably between the three plants, being most intense and long lasting at plant A. At plant B, organic solvents were used also for degreasing of sheep skins. During the 1970 s, the organic solvent based paints were gradually, and to a large extent, exchanged with water based paints. In the departments where dry products were handled, there had been exposure to leather dust. Specific work tasks with high exposures have been identified. According to the panels, dust from chromium tanned leather may contain up to $8 \%$ chromium, together with preservatives and dyestuffs.

ASSESSMENT OF EXPOSURE

At the time of the investigation, 1994, the plants had been shut down for three to four years, and no direct exposure assessment could therefore be performed. The work history for each case and control was investigated by an occupational hygienist (AS) with the assistance of expert panels including former long term employees with a good knowledge of the employees and the production. The occupational hygienist and the assisting panels had no knowledge of the health status of the subjects investigated. Moreover, to avoid a differential misclassification of exposure, no direct contact was made with cases and controls still alive.

The exposure variables of interest were:

Recognised or possible exposure to specific chemical carcinogens

Aniline or azo dyes, arsenic, chromium, formaldehyde, mercury compounds, organic solvents, chlorophenols, vegetable tannins (wood extracts), and leather dust.

\section{Exposure level}

The individual exposures to each of these substances were estimated according to a four step ordinal scale, $0-3$. The level was set at 0 when the substance was not used at the department at which the subject worked, or when a simultaneous use at any other department of the plant was unlikely to have polluted the work environment of the subject in question. Level 1 was chosen for subjects working in areas which were thought to be contaminated from adjacent departments or areas. Level 2 was set for subjects working in contaminated areas but not directly involved in the work tasks producing the highest air pollution. The highest exposure level (3) was set for those work tasks that were performed in heavy exposure sites recognised by the expert panel, and also supported by a description of the technical procedure.

\section{Exposure time}

If, at a certain point of time, there was a known change in the level of exposure to any of these substances, this was registered as a new exposure period.

\section{Frequency of exposure}

$0-100 \%$ of the workday.

\section{Exposure index used in the analyses}

If a person was exposed with an exposure level $>1$, the exposure index was calculated as: frequency of exposure $\times$ exposure time $=$ cumulative exposure in years; otherwise the index was set to 0 . Due to small number of cases with exposure levels $2-3$, the original four step scale for exposure level could unfortunately not be used. Thus, exposure level 0 was regarded as "unexposed" and exposure levels $1-3$ as "exposed".

\section{Assessment of tobacco consumption}

Also, the tobacco consumption could be estimated for most people by the expert panels already mentioned (table 1). The consumption of cigarettes was registered as; $0,1-10$, or $>10$ cigarettes a day. The consumption of 
Table 1 Distribution and description of cases and controls for sex, plant, and matched sets

\begin{tabular}{|c|c|c|c|c|c|c|}
\hline & \multirow{2}{*}{$\begin{array}{l}\text { Cases } \\
n(\%)\end{array}$} & \multirow{2}{*}{$\begin{array}{l}\text { Controls } \\
n(\%)\end{array}$} & \multirow{2}{*}{$\begin{array}{l}\text { Total } \\
n\end{array}$} & \multicolumn{3}{|c|}{ Matched sets* } \\
\hline & & & & $1 / 1$ & $1 / 2$ & $1 / 3$ \\
\hline \multicolumn{7}{|l|}{ Plant: } \\
\hline A & $6(9)$ & $17(10)$ & 23 & - & 1 & 5 \\
\hline B & $47(69)$ & $121(68)$ & 168 & 2 & 16 & 29 \\
\hline $\mathrm{C}$ & $15(22)$ & $40(22)$ & 55 & - & 5 & 10 \\
\hline All & $68(100)$ & $178(100)$ & 246 & 2 & 22 & 44 \\
\hline \multicolumn{7}{|l|}{ Smoking habits: } \\
\hline Smokers & $40(59)$ & $91(51)$ & - & - & - & - \\
\hline Non smokers & $5(7)$ & $24(13)$ & - & - & - & - \\
\hline No data available & $23(34)$ & $63(36)$ & - & - & - & - \\
\hline \multicolumn{7}{|l|}{ Sex: } \\
\hline Men & $60(88)$ & $159(89)$ & - & - & - & - \\
\hline $\begin{array}{l}\text { Calendar year of } \\
\text { diagnosis } f\end{array}$ & $1978(1959-1989)$ & - & - & - & - & - \\
\hline Age at diagnosis $\uparrow$ & $66(43-84)$ & - & - & - & - & - \\
\hline
\end{tabular}

${ }^{\star} 1 / 1=1 \mathrm{control} /$ case, $1 / 2=2$ controls $/$ case, $1 / 3=3$ controls $/$ case.

†Median (range).

Table 2 Association between cumulative exposure to different occupational agents in leather tanning and pancreatic cancer (cases and controls had been employed for at least six months and at least 10 years had elapsed between start of exposure and cancer)

\begin{tabular}{|c|c|c|c|c|c|}
\hline Exposure & $\begin{array}{l}\text { Cumulative } \\
\text { exposure }(y)\end{array}$ & $\begin{array}{l}\text { Cases } \\
n=10\end{array}$ & $\begin{array}{l}\text { Controls } \\
n=27\end{array}$ & $\begin{array}{l}\text { Adjusted } \\
\mathrm{OR}^{\star}(95 \% \mathrm{CI})\end{array}$ & $\begin{array}{l}\text { Unadjusted } \\
\text { OR }(95 \% C I)\end{array}$ \\
\hline Aniline and & 0 & 8 & 23 & $1.00-$ & $1.00-$ \\
\hline azo dyes & $\geqslant 0.5$ & 2 & 4 & $1 \cdot 27(0 \cdot 19-8 \cdot 48)$ & $1.44(0.22-9.41)$ \\
\hline \multirow[t]{2}{*}{ Chrome salts } & 0 & 10 & 22 & $1.00-$ & $1.00-$ \\
\hline & $\geqslant 0.5$ & 0 & 5 & -- & - - \\
\hline \multirow[t]{2}{*}{ Formaldehyde } & 0 & 10 & 20 & $1.00-$ & 1.00 \\
\hline & $\geqslant 0.5$ & 0 & 7 & -- & $-\quad-$ \\
\hline \multirow[t]{2}{*}{ Chlorophenols } & 0 & 9 & 22 & $1.00-$ & $1.00-$ \\
\hline & $\geqslant 0.5$ & 1 & 5 & $0.53(0.05-4.90)$ & $0.49(0.05-4.80)$ \\
\hline \multirow[t]{2}{*}{ Mercury } & 0 & 9 & 23 & $1.00-$ & $1.00-$ \\
\hline & $\geqslant 0.5$ & 1 & 4 & $0.69(0.05-8.04)$ & $0.64(0.06-6.52)$ \\
\hline \multirow[t]{2}{*}{ Organic solvents } & 0 & 9 & 19 & $1.00-$ & $1.00-$ \\
\hline & $\geqslant 0.5$ & 1 & 8 & $0.25(0.03-2.42)$ & $0.26(0.03-2 \cdot 44)$ \\
\hline \multirow[t]{2}{*}{ Arsenic } & 0 & 10 & 24 & $1.00-$ & $1.00-$ \\
\hline & $\geqslant 0.5$ & 0 & 3 & -- & -1 \\
\hline \multirow[t]{2}{*}{ Wood dust } & 0 & 9 & 25 & $1 \cdot 00-$ & $1 \cdot 00-$ \\
\hline & $\geqslant 0.5$ & 1 & 2 & $1.73(0 \cdot 10-30 \cdot 79)$ & $1.39(0.19-17 \cdot 25)$ \\
\hline \multirow[t]{2}{*}{ Leather dust } & 0 & 2 & 20 & $1.00-$ & $1.00-$ \\
\hline & $\geqslant 0.5$ & 8 & 7 & $7 \cdot 19(1.44-35.9)$ & $11.43(1.94-67.29)$ \\
\hline
\end{tabular}

${ }^{\star} \mathrm{OR}$ adjusted to matching factors (age at risk, sex, and plant).

Table 3 Association between cumulative exposure to different occupational agents in leather tanning and lung cancer (cases and controls had been employed for at least six months and at least 10 years had elapsed between start of exposure and cancer)

\begin{tabular}{|c|c|c|c|c|c|}
\hline Exposure & $\begin{array}{l}\text { Cumulative } \\
\text { exposure }(y)\end{array}$ & $\begin{array}{l}\text { Cases } \\
n=22\end{array}$ & $\begin{array}{l}\text { Controls } \\
n=55\end{array}$ & $\begin{array}{l}\text { Adjusted } \\
O R^{\star}(95 \% C I)\end{array}$ & $\begin{array}{l}\text { Unadjusted } \\
\text { OR }(95 \% \text { CI })\end{array}$ \\
\hline $\begin{array}{l}\text { Aniline and } \\
\text { azo dyes }\end{array}$ & $\stackrel{0}{\geqslant 0.5}$ & $\begin{array}{r}21 \\
1\end{array}$ & $\begin{array}{r}51 \\
4\end{array}$ & $\begin{array}{l}1.00- \\
0.63(0.06-5.68)\end{array}$ & $\begin{array}{l}1.00- \\
0.61(0.06-5.76)\end{array}$ \\
\hline \multirow[t]{2}{*}{ Chrome salts } & 0 & 21 & 52 & $1.00-$ & $1.00-$ \\
\hline & $\geqslant 0.5$ & 1 & 3 & $0.81(0.08-7.84)$ & $0.83(0.08-8.40)$ \\
\hline \multirow[t]{2}{*}{ Formaldehyde } & 0 & 17 & 45 & $1.00-$ & $1.00-$ \\
\hline & $\geqslant 0.5$ & 5 & 10 & $1.25(0.38-4 \cdot 12)$ & $1.32(0.39-4.44)$ \\
\hline \multirow[t]{2}{*}{ Chlorophenols } & 0 & 21 & 41 & $1.00-$ & $1.00-$ \\
\hline & $\geqslant 0.5$ & 1 & 14 & $0.16(0.02-1.23)$ & $0 \cdot 14(0.02-1 \cdot 13)$ \\
\hline \multirow[t]{2}{*}{ Mercury } & 0 & 18 & 51 & $1.00-$ & $1.00-$ \\
\hline & $\geqslant 0.5$ & 4 & 4 & $2.33(0.58-9.37)$ & $2.83(0.64-12.53)$ \\
\hline \multirow[t]{2}{*}{ Organic solvents } & 0 & 15 & 48 & $1.00-$ & $1.00-$ \\
\hline & $\geqslant 0.5$ & 7 & 7 & $3.54(1.00-12.64)$ & $3.20(0.97-10.59)$ \\
\hline \multirow[t]{2}{*}{ Arsenic } & 0 & 18 & 45 & $1.00-$ & $1.00-$ \\
\hline & $\geqslant 0.5$ & 4 & 10 & $1.00(0.27-3.71)$ & $1.00(0.28-3.60)$ \\
\hline \multirow[t]{2}{*}{ Wood dust } & 0 & 22 & 52 & $1.00-$ & $1.00-$ \\
\hline & $\geqslant 0.5$ & 0 & 3 & $-\quad-$ & $-\quad-$ \\
\hline \multirow[t]{2}{*}{ Leather dust } & 0 & 14 & 31 & $1.00-$ & $1.00-$ \\
\hline & $\geqslant 0.5$ & 8 & 24 & $0.69(0.23-2.05)$ & $0.74(0.27-2.05)$ \\
\hline
\end{tabular}

${ }^{\star} \mathrm{OR}$ adjusted to matching factors (age at risk, sex, and plant).

pipe tobacco or snuff was registered as yes or no. There was no significant association between any of the chemical exposure indices and smoking habits.

\section{STATISTICS}

The data were analysed by means of conditional logistic regression, ${ }^{18}$ with EGRET computer software (Statistics and Epidemiology Research Corporation, Seattle, US, 1990). As incidence density sampling (described earlier) was applied, the odds ratio (OR) is a consistent estimator of the incidence ratio and, as the diseases considered are rare, also of the risk ratio. ${ }^{19}$ The ORs presented are adjusted for the matching factors (age at risk, sex, and plant). We also considered calendar time as a potential confounder, which was divided into four periods (1958-72, 1973-8, 1979-84, 1985-91), with almost equal numbers of cases and controls (see Discussion).

\section{Results}

A weak association was found between exposure to leather dust and the total incidence of all tumours that had earlier been thought to be associated with leather tanning ( $>5$ years of exposure; OR 1.41, 95\% CI 0.69-2.88). Considering exposure to leather dust from vegetable tanning only, the $O R$ increased to $8 \cdot 92$ (95\% CI $2 \cdot 48-32 \cdot 17)$. None of the other exposures showed any such noteworthy association with cancer incidence.

The incidence of pancreatic cancer was affected by exposure to leather dust (OR $7 \cdot 19$, $95 \%$ CI 1.44-35.89; table 2 ), but not by any of the other exposures. Considering leather dust from vegetable tanning only, all four cases were exposed $v$ one of 11 controls.

A significant association was found between exposure to organic solvents and lung cancer (OR 3.54, 95\% CI 1.00-12.64; table 3). Adjustment for smoking habits did, however, decrease the OR to 1.98 (95\% CI 0.50-7.75). An association was also indicated between leather dust from vegetable tanning and lung cancer, as four out of five cases were exposed $v$ none of 13 controls. None of the other occupational exposures were associated with lung cancer.

The association between exposure to leather dust and soft tissue sarcomas was based on only four incident cases and is therefore difficult to interpret (OR 3.79, 95\% CI $0 \cdot 30-48 \cdot 00)$. None of the subjects with soft tissue sarcomas had been exposed to chlorophenols. We could not find any noteworthy association between any of the chemical exposure indices and stomach, kidney, and bladder cancer.

\section{Discussion}

The main result of this study was that the hypothesis of an association between exposure to chlorophenols and risk of soft tissue sarcomas, based on the results from the previous cohort study, ${ }^{16}$ was not supported. Interestingly, the present analysis showed a significant association between exposure to leather dust and pancreatic cancer. Moreover, exposure to leather dust from vegetable tanning was often a factor in cases with lung cancer.

Information on specific work tasks, derived from company records, was available for only $27 \%$ of the cohort members. ${ }^{16}$ The present cohort based case-control study was therefore performed to enhance the quantity and quality of the individual exposure estimates. There is, 
however, still an apparent problem as there are no good exposure assessments, which to a large extent can be explained by the fact that the plants had already been closed down when the study was performed. The non-differential exposure misclassification is therefore probably not negligable. The occupational hygienist and the exposure assessment panels were, however, not aware of which subjects were cases or controls. A differential misclassification of exposure is therefore unlikely.

The mortality may be higher among short term employees, compared with those who were employed longer, ${ }^{20}$ probably due to socioeconomic confounding factors. To prevent this affecting the results the study base was restricted to subjects employed for at least six months.

As this study was not matched on calendar year of diagnosis of the case, the effect estimates were also adjusted for this variable. However, calendar year did not act as a confounding factor.

We used a simple method for taking into account latency and induction-that is, exclusion of subjects from analysis during the first 10 years since the start of employment. Indeed, exposure lagging may be preferable to this method. ${ }^{17}$ However, our results seemed to be consistent with results obtained by applying the exposure lag technique, with a 10 year lag period, in the data analysis. An induction latency time of at least 10 years seems to be reasonable for the exposure-disease relations considered in the present study. The evaluation of applying a 20 years induction latency period was hampered by a low statistical power, but the effect estimates did not change noticeably.

Exposure to chlorophenols has in some studies been associated with soft tissue sarcomas. ${ }^{92122}$ In the present study three of the four cases of soft tissue sarcomas had been employed during the periods when chloropenols had been used, but none of them had been exposed. Thus, our results did not give any support to an association between exposure to chlorophenols and soft tissue sarcomas, but on the other hand, due to small numbers such an association could also not be rejected. Three of the cases of soft tissue sarcoma had been exposed to leather dust for one, five, and 12 years. The $95 \%$ CI for this enhanced OR was, however, extremely wide.

The case with nasal cancer had not been exposed to either leather dust or to any of the other occupational agents. Thus, no support was given to the suspected association between exposure to leather dust and sinonasal cancer in the tanning industry. ${ }^{515}$

In the previous cohort study we found a numerical but non-significant increase for lung cancer. A plausible explanation for this slightly increased risk may be a higher proportion of smokers among the leather workers than in the general population. This was supported by $80 \%$ smokers among those cases and controls, for whom the smoking habits were known. Smoking habits were not significantly associated with the assessed chemical exposure indices. In spite of that, the OR for exposure to organic solvents and lung cancer decreased when adjusted for smoking habits. Exposure to leather dust from vegetable tanning was often present in the lung cancer cases. Vegetable tannins, which are derived from different types of hardwood and consist of macromolecules with polyphenolic groups, form bonds with collagen. ${ }^{123}$ Animal studies have shown that tannins have carcinogenic properties. $^{23}$

An association between leather tanning and mortality from pancreatic cancer has previously been found in a Swedish community based case-control study. ${ }^{6} \mathrm{~A}$ slight non-significantly increased incidence of pancreatic cancer was found also in our previous cohort study. ${ }^{16}$ It is therefore interesting that in the present study exposure to leather dust was associated with the incidence of this neoplasm. It is also noteworthy that, as for lung cancer, the association seems to be more obvious for leather dust from the vegetable tanning process. It should, however be born in mind that in our cohort the start of vegetable tanning generally had taken place earlier than for chromium tanning. Latency induction periods of several decades are often considered as biologically relevant for solid tumours. Thus, the full effect of chromium tanning may not yet be possible to evaluate.

It should be pointed out that no adjustments for multiple comparisons were made in the present study, according to recommendations put forward in the epidemiological literature. ${ }^{24}$

This study is the first attempt to pinpoint the causative agents of cancer in the leather tanning industry more specifically. The relatively few incident cancer cases in the study base puts a limit to the statistical power in assessing associations between different occupational exposures and specific tumours. This is important to bear in mind, in particular when considering the results obtained for specific tumours. A follow up of the study base will provide more cases and enhance the possibility for a more conclusive evaluation of the study.

G Persson and U Wallin are gratefully acknowledged for their excellent and most valuable assistance $\mathrm{E}$ Andersson, $\mathrm{E}$ Bergdahl, E Ek, J Ekblom, K-O Geweniger, B Kelvegård, G Nilsson, S Nilsson, and E Schlüter are gratefully acknowledged for generously assisting with the exposure assessment. This project was supported by grants from the Klippan Leatherworker's Fund, the Swedish Work Environment Fund, the Swedish Cancer Society, and the Medical Faculty at the University of Lund.

1 International Agency for Research on Cancer. LARC monographs on the evaluation of the carcinogenic risk of chemicals to humans-wood, leather, and some associated industries. Vol 25. Lyon: IARC, 1981 .

2 Garabrant DH, Wegman DH. Cancer mortality among shoe and leather workers in Massachusetts. Am F Ind Med 1984;5:303-14.

3 Sweeny MH, Walrath J, Waxweiler J. Mortality among retired fur workers. Dyers, dressers (tanners) and service workers. Scand $¥$ Work Environ Health 1985;11:257-64.

4 Coggon D, Pannett N, Osmond C, Acheson ED. A survey of cancer and occupation in young and middle aged men I. Cancers of the respiratory tract. Br $\mathcal{F}$ Ind Med 1986; 43:332-8.

5 Pippard EC, Acheson ED, Winter PD. Mortality of tanners. Br F Ind Med 1985;42:285-7.

6 Edling C, Kling H, Flodin U, Axelson O. Cancer mortality among leather tanners. $B r f$ Ind Med 1986;43;494-6.

7 Stern FB, Beaumont J, Halperin WE, Murthy LI, Hills BW, Fajen JM. Mortality of chrome leather tannery 
workers and chemical exposure in tanneries. Scand $\mathcal{F}$ Work Environ Health 1987;13:108-17.

8 Malker HR, Malker BK, McLaughlin JK, Blot WJ. Kidney cancer among leather workers. Lancet 1984;i:56.

9 Constantini A, Paci E, Miligi L, Buiatti E, Martelli C, Lenzi S. Cancer mortality among workers in the Tuscan tanning industry. $\mathrm{Br}$ F Ind $\mathrm{Med} 1989 ; 46: 384-8$.

10 Cole P, Hoover R, Friedell GH. Occuaption and cancer of the lower urinary tract. Cancer 1972;29:1250-60.

11 Vineis P, Magnani C. Occupation and bladder cancer in males: a case-control study. Int $f$ Cancer 1985;35: 599-606.

12 Acheson ED, Pippard EC. Kidney cancer among leather workers. Lancet 1984;i:563.

13 Cartwright RA, Boyko RW. Kidney cancer among leather workers. Lancet $1984 ; \mathbf{i}: 850-1$

14 Pippard EC, Acheson ED. The mortality of boot and shoe makers, with special reference to cancer. Scand $\mathcal{F}$ Work Environ Health 1985;11:249-55.

15 Comba P, Battista G, Belli S, de Capua B, Merler E, Orsi D et al. A case-control study of cancer of the nose and paranasal sinuses and occupational exposures. $A m \mathcal{F}$ Ind Med 1992;22:511-20.

16 Mikoczy Z, Schütz A, Hagmar L. Cancer incidence and mortality among Swedish leather tanners. Occup Environ Med 1994;51:530-5.

17 Checkoway H, Pearce NE, Crawford-Brown DJ. Mono- graphs in epidemiolgy and biostatistics. Vol 13 (research methods in occupational epidemiology). New York: Oxford University Press, 1989.

18 Hosmer DW, Lemeshow S. Applied logistic regression. New York:Wiley, 1989

19 Greenland S, Thomas DC. On the need for the rare disease assumption in case-control studies. Am f Epidemiol 1982; 116:547-53

20 Gilbert ES. Some confounding factors in the study of mortality and occupational exposures. Am 7 Epidemiol 1982;

21 Bertazzi PA, Pesatori AC, Consonni D, Tironi A, Landi MT, Zochetti C. Cancer incidence in a population accidentally exposed to 2,3,7,8-tetrachlorodibenzo-paradioxin. Epidemiology 1993;4:398-406.

22 Kogevinas M, Kauppinen T, Winkelmann R, Becher $H$, Bertazzi PA, Bueno de Mesquita HB, et al. Soft-tissue sarcoma and non-Hodgkin's lymphoma in workers exposed to chlorophenoxy herbicides, chlorophenols, and dioxins: two nested case-control studies. Epidemiology 1995;6:396-402

23 International Agency for Research on Cancer. IARC monographs on the evaluation of carcinogenic risk of chemicals to
man-some naturally occurring substances. Vol 10. Lyon: IARC, 1976 .

24 Rothman KJ. No adjustments are needed for multiple comparisons. Epidemiology 1990;1:43-6. 